\title{
URBANISTINIŲ STRUKTŪRŲ FORMAVIMO IR ŽEMĖS NAUDOJIMO KLASIFIKAVIMO PROBLEMATIKA
}

\author{
Pranciškus Juškevičius ${ }^{1}$, Kristina Jauneikaite ${ }^{2}$ \\ ${ }^{1}$ Urbanistikos katedra, Vilniaus Gedimino technikos universitetas, \\ Pylimo g. 26/Trakų g. 1, LT-01332 Vilnius, Lietuva.El.paštas sj@amstudio.lt \\ ${ }^{2}$ Miestu statybos katedra, Vilniaus Gedimino technikos universitetas, \\ Sauletekio al. 11, LT-10223 Vilnius, Lietuva.El.paštas kris@ap.vgtu.lt \\ Itteikta 20080526
}

\begin{abstract}
Santrauka. Urbanistinių struktūrų formavimas ir sisteminis įvertinimas išlieka kaip viena iš svarbiausių problemų, kurios egzistavimas mažina planavimo efektyvumą. Esminiai neigiami veiksniai slypi neišvystytoje ir nesistemiškoje planavimo sistemoje. Struktūrų formavimas nepatenka ị didžiausio suinteresuotumo ratą, palyginti su žemes savininkų ir investuotojų suinteresuotumu padidinti žemės naudojimo įvairovę ir vertę bei grąžą. Dabartinejje praktikoje sektorinių institucijų procedūrinis dalyvavimas iggauna monopolinį ir nediskutuojamą pobūdį, o planavimo sistemoje ịteisinta vienintelè politinio ịvertinimo forma negarantuoja objektyvumo. Žemès naudojimo paskirtys, būdai ir pobūdžiai nekoreliuoja su urbanistinio planavimo tikslais, objektų fizine ir funkcine įvairove. Straipsnyje nagrinèjamos urbanistinių struktūrų formavimo sąsajos su žemės naudojimo klasifikavimo principais, informaciniu aprūpinimu, struktūrų ịvertinimo principais, vystymo tikslais ir jų reikšmės kaitos koreliacija su susisiekimo ir informacinių technologijų raida. Pateikiamos prielaidos urbanistinių struktūrų formavimo problemoms spręsti: liberalizuoti ir perduoti planuotojo kompetencijai žemės naudojimo tipų ir formų bei reglamentų išsamaus turinio pagrindimą, i̇vertinant, kad keičiasi urbanistinių struktūrų forma, vaidmuo ir reikšmè miesto funkcionavimui, pereiti prie kokybiškai naujo sisteminio ịvertinimo, paremto miesto e. modeliais ir išorès efektų identifikavimu bei jų monetarizavimu.

Reikšminiai žodžiai: planavimo sistema, struktūra, morfologija, žemès naudojimo tipai, sisteminio įvertinimo kriterijai, išorès efektai.
\end{abstract}

\section{Ivadas}

Teritorijų ir urbanistinio planavimo požiūriu pastarieji $4 \mathrm{~m}$. Lietuvoje buvo ypatingi, nes tai buvo miestų ir savivaldybių teritorijų bendrųjų planų rengimo iki tol neregèto masto vajus. To vajaus pasekmè - maždaug per $3 \mathrm{~m}$. daugiau kaip su 50 bendrųjų planų buvo užkamšytos beveik $20 \mathrm{~m}$. didžiosios spragos ir išryškinta daugybė problemų, kurių šaknys slypi ydingoje teritorijų planavimo sistemoje. Atkūrus Lietuvos nepriklausomybę pirmojo teritorijų planavimo i̇statymo (1995 m.) nuostatų vystymas vyko vangiai, nes besiformuojančios rinkos sąlygomis vangiai vyko ir bendrasis planavimas - apie 10 bendrųjų planų per $10 \mathrm{~m} .2004 \mathrm{~m}$. pasirodęs antrasis teritorijų planavimo ịstatymas buvo radikalus, tačiau sistemine prasme buvo žengtas žingsnis atgal. Naujas reikalavimas rengti SPAV - strateginius pasekmių aplinkai vertinimus - buvo nepagrisstas informacinio aprūpinimo požiūriu, nuolatinès ịstatymo, ịstatymo igyvendinamųjų aktų pataisos nesudarè tinkamos planuoti aplinkos.
Šio straipsnio tikslai yra susiję su dviem aplinkybèmis. I-ame urbanistikos forume per diskusijas iš esmès buvo konstatuota teritorijų planavimo sistemos krizė (tiesa, oficialaus pripažinimo nebuvo). $2008 \mathrm{~m}$. II-ame forume buvo pristatyti pasiūlymai, kurie panaikintų klaidas, netikslumus ir būtų gairès sistemai modernizuoti (Darnioji plètra ... 2008). Šio straipsnio tikslas papildyti ne tokius diskutuotus urbanistinių struktūrų ir žemès naudojimo klasifikavimo probleminius dalykus platesniame planavimo sistemos kontekste.

\section{Problema}

Esamos planavimo sistemos svarbiausias požymis - nesistemiškumas. Ryškiausias faktas yra tas, kad specialieji planai yra viršesni už bendruosius planus. Dèl to atsiranda įvairiausio tipo atskirčių: teritorinių, kai miesto ar rajono savivaldybès dalies vystymas igyja socialinès ir ekonominès atskirties pobūdį, neturintị apribojimus 
kompensuojančių priemonių ar mechanizmų; sektorinių, kai joms atstovaujančios institucijos iš esmès nepripažista kompromisinių sprendinių. Taip bendrasis planavimas netenka sisteminio efektyvumo.

Žinomi atvejai, kai rajonų savivaldybių specialieji gyvenamujjų teritorijų planai buvo traktuojami kaip bendrojo plano pakaitalas, nors jie nieko bendra neturi su realiu gyvenamosios funkcijos poreikiu (viršija realų dešimtimis kartų), tokių teritorijų struktūrizavimu, socialine ir kita infrastruktūra.

Pagrindinės žemės naudojimo paskirtys nekoreliuoja su urbanistinio planavimo tikslais ir uždaviniais. Paskirtys sumaišytos su nuosavybe; su veiklos ar vystymo režimu; užstatytos ir urbanizuotos teritorijos apskritai neidentifikuojamos, nors jos šalies pažangos variklis, o dalyko požiūriu žemès naudojimo įvairovè ir jos dinamika yra didžiausia. Teritorijų planavimo sistemoje formalizuotos ir privalomos naudoti žemès naudojimo paskirtys, būdai ir pobūdžiai nesusieti su planavimo tikslais, objektų fizine ir funkcine įvairove. Neįvertintas informacijos gavimo galimybès ir prognozès neapibrèžtumo egzistavimas. Visa tai tolina darnių daugiafunkcių struktūrų formavimo galimybes.

\section{Urbanistinès struktūros ir morfologija}

Paprasčiausias struktūros apibūdinimas - daikto dalių tarpusavio išsidèstymas ir ryšys. Urbanistikoje daikto dalys gali būti namas ar kitoks statinys; didelès ir mažos teritorijos, kurių visuma suformuoja namų grupę, kvartalą, įvairiausius kompleksus, miestą kartu su neatskiriamu gatvių, kelių ir kitų komunikacinių koridorių tinklu bei kitais fiziniais elementais, politini miestą, kaip faktinio miesto ar aglomeracijos bei metropolio dali, miestą, kaip gyvenviečių ar tik miestų sistemos dalị. Taigi urbanistinès struktūros yra hierarchinès.

Tokią struktūrą apibūdina morfologinių požymių sklaida konkrečios hierarchijos teritorijoje. Požymiai: forma, vaizdas, proporcijos, simetriškumas, ritmas, tankis, nenutrūkstamumas, stilius ir t. t. Jie atspindi miesto kūrimo laikotarpių materialinę kultūrą. Paprastai tokia struktūra vadinama fizine struktūra.

Fizinę struktūrą papildžius funkciniais požymiais, identifikuojama funkcinè morfostruktūra. Abu struktūrų tipai yra susiję. Tačiau pastaraji šimtmeti funkcinę morfostruktūrą labiau formavo idèjos, koncepcijos ir teorijos. Pradžią grynajam funkcionalizmui dave I Aténų charta. Jo esmé - funkciné dezintegracija. Tai principas, kai pastatai su jų sklypais skaidomi $\mathfrak{i}$ maksimaliai vienarūšius tipus ir jie koncentruojami ị labai didelius vienarūšius ar siaurai specializuotus rajonus, zonas, centrus. Privalumai buvo grindžiami vienfunkciškumo, pavyzdžiui, vien gyvenamosios, vien gamybos, rekreacijos privalumais. Tačiau vidiniai privalumai virsta esminèmis miesto funkcionavimo problemomis, nes struktūrinių dalių egzistavimą garantuoja tik maksimizuota susisiekimo funkcija. Šis principas visuotinai pripažintas kaip miestų krizės, prasidejusios prieš 20-30 m., esmine priežastis. Ivvairiomis formomis idejja išlikusi planavimo sistemoje.

Dabartinè visuotinai pripažinta ir oficiali, nuolat pabrèžiama planavimo koncepcija yra darnioji plètra (jos turiniui perteikti tikslesnis atitikmuo anksčiau vartota sąvoka subalansuotas vystymas). Svarbiausi tikslai - funkcinè integracija, struktūrinis daugiafunkciškumas, susisiekimo viešuoju transportu maksimizavimas, o lengvuoju automobiliu - minimizavimas, gebẻjimas valdyti urbanistinị vystymąsi. Ši koncepcija yra funkcinio zonavimo antonimas.

Reali situacija yra sudètingesnè, nes tuo pačiu oficialių koncepcijų ir teorijų galiojimo metu vyksta savaiminiai urbanistinių struktūru kaitos procesai. Vienas iš naujesnių - vadinamasis sklypinis planavimas, kurio varomoji jèga yra asmeniniai interesai. Antrasis yra galingesnis ir sudètingesnis - metropolizacijos procesas, suprantamas kaip šiuolaikinè, tačiau sunkiai valdoma, tolesnès urbanizacijos forma. Metropolizacijos ekspansijos zonos struktūra yra chaotiška, sunkiai apibūdinama, nes neturi požymių, būdingų klasikiniam ir funkcionalizmo laikotarpio miestui (Juškevičius, Valeika 2007). Trečiasis - vis didejjanti planuotojo priklausomybè nuo politikų kompetencijos ir suinteresuotumo bei profesinių urbanistinio planavimo žinių.

Remiantis šiomis mintimis galima tvirtinti, kad dabartinè teritorijų planavimo sistema yra dviprasmiška. Pirma, ji konservatyvi, nes iki šiol nesugebèjo įvertinti ir atsikratyti funkcinio zonavimo principų. Antra, nesugeba identifikuoti šiuolaikinių dinaminių procesų, todèl neturi ir priemonių jiems valdyti. Todèl yra didelè įvairiausio turinio konfliktų tikimybè (tą patvirtina praktika), kuriems išspręsti sistema nenumatė arbitrų instituto.

Lietuvos urbanistikoje mažiausiai žinomas trečias tipas - socialinė miestų morfologija. Tai socialinių, demografinių, etninių požymių sklaidos miesto erdvejje analizès rezultatas. Klasikiniai socialiniai modeliai: E. W. Burgess (1926) 5 koncentrinių zonų (pagal požymius įtakingi, turtingesni sluoksniai, darbininkai, I-os ir II-os kartos imigrantai, getai, landynès), sektorinis H. Hoyt (1939), daugiabranduolinis C. D. Haris 
ir E. L. Ullman (1945) modeliai (Goodal 1987). Realiai socialinès segregacijos, socialinès deviacijos nèra urbanistinès analizès ir planavimo objektas.

Struktūrų ir jų morfotipų identifikavimo galimybès priklauso nuo pradinių elementų skaičiaus. Minimalus 2-3 elementų skaičius neatskleis požymių ir ypatybių teritorinès sklaidos. Jeigu reikalingas didelis jų skaičius, kyla informacinio aprūpinimo problema. Svarbiausia ar bus galimybė nustatyti teritorinių elementų fizinị, funkcinị turinị.

Urbanistinio planavimo reikmèms šalyje neveikia jokia speciali informacinè sistema, retas miestas turi savą GIS. Oficialios ir prieinamos statistinès sistemos pagrindinis objektas yra administraciniai vienetai. Svarbiausias trūkumas - nèra bendros teritorinių vienetų sistemos. Palyginkime Londono teritorijos padalinimo statistinėms reikmėms lankstumą (Stachowiak 2004):

\begin{tabular}{lccr}
\hline & $\begin{array}{r}\text { Elementuc } \\
\text { skaičius }\end{array}$ & $\begin{array}{r}\text { Vidutinis } \\
\text { plotas, ha }\end{array}$ & $\begin{array}{r}\text { Vidutinis } \\
\text { gyventoju } \\
\text { skaičius }\end{array}$ \\
\hline $\begin{array}{l}\text { Pradiniai } \\
\text { elementai }\end{array}$ & 24140 & 6 & 297 \\
\hline $\begin{array}{l}\text { Agreguoti } \\
\text { elementai }\end{array}$ & 4765 & 33 & 1505 \\
\hline Apylinkès & 633 & 249 & 11330 \\
\hline $\begin{array}{l}\text { Dideli } \\
\text { rajonai }\end{array}$ & 33 & 4768 & 217336 \\
\hline Iš viso & & 157343 & 7172091 \\
\hline
\end{tabular}

Per daug smulkus struktūrizavimas išgrynina smulkių elementų vienfunkciškumą. Tai sukuria tokią mozaiką, kuri bendrojo planavimo srityje neturi nei praktinès, nei teorinès prasmès. Siekiant kompromiso tinka teritorinio integralumo principas:

a. elementarų integracijos lygmenį užtikrina susisiekimas pésčiomis ne didesniame kaip $0,9 \mathrm{kv}$. km plote. Tai koreliuoja su pagrindinių gatvių tinklo sukuriamų teritorijų dydžiais. Priklausomai nuo gyventojų tankio susidarys didesnis ar mažesnis gyventojų skaičius ir atitinkamai darbo jègos potencialas bei paslaugų rinka. Nuo to priklausys, kiek ir kokios funkcijos papildys gyvenamąją arba apskritai sudarys tokios teritorijos funkcinę visumą;

b. miesto lygmenyje susisiekimas viešuoju transportu ir lengvaisiais automobiliais užtikrina funkcinę ir teritorinę integraciją ne didesniuose kaip $100 \mathrm{kv}$. km plotuose. Tai jau daug didesnè rinka ir aukštesnio rango integracija. Atitinkamai labiau išvystyta socialinè ir darbo infrastruktūra; c. jeigu plotai didesni, teritorinès integracijos laipsnis mažèja. Integracija įmanoma, jeigu neviršijama mobilumo konstanta $\mathrm{m}<45 \mathrm{~min}$. Kiekvieną aukštesnị integracijos lygmenį formuoja didesnio greičio $v$ susisiekimas. Jeigu $v=50 \mathrm{~km} / \mathrm{h}$, integruotas plotas $F<1000$ kv. km, o forma tik iš dalies išlieka kompaktiška, tai bus didmiesčio ir iš dalies metropolio integracinis lygmuo, kuriame ryškèja linijinès formos elementai;

d. jeigu susisiekimo greitis didejja nuo 70 iki $200 \mathrm{~km} / \mathrm{h}$, atsiranda vadinamasis tunelio efektas. Tokiu atveju nyksta kompaktinis teritorinis integruotumas ir atsiranda dispersinès formos funkcinè integracija.

\section{Struktūrų formavimo tikslai}

Lietuvos miestai turi unikalias, palaipsniui susiklosčiusias struktūras, kurių vaidmuo miesto sistemos funkcionavimui yra nevienodas. Šalies miestų planavimas dabar yra jų struktūrų pertvarkymas ir vystymas, o ne laisvas kūrimas. Struktūros yra inertiškos. Tai yra esminis veiksnys, suvaržantis planavimo variantiškumą. Kartu ir efektyvesnio varianto paiešką. Yra ir kitoks veiksnys - metropolizacijos procesas, kurio savaiminès teritorinès sklaidos valdymo efektyvumas Lietuvoje yra minimalus, kaip ir daugybeje kitų šalių. Be to, metropolinių struktūrų formavimasis turi privalumų ir trūkumų, kartu šalininkų ir priešininkų pozicijos yra nesuderinamos. Taigi ir tikslų formulavimo ìvairove gali būti didelè.

Miestų struktūrų pertvarkymas ir vystymas a priori siejamas su ịsitikinimu, kad tai duos teigiamų rezultatų. Tačiau planavimo sistema neturi struktūrų, kaip ir visos miesto sistemos įvertinimo metodikos. Todèl vienu atveju ịvertinimas virsta kokybiniu aptarimu, kuris gali būti priimtinas fizinei struktūrai įvertinti tol, kol naudojami įvaizdžio, stiliaus, ritmo ir panašūs morfologiniai požymiai. Kitais atvejais, kai naudojami fizinès, funkcinès ir socialinès morfostruktūros požymiai, struktūrų efektą galima nustatyti tik subjektyviai, ypač pasitelkus balsavimo mechanizmą.

Šio teiginio pagrindinis argumentas yra toks: struktūrą apibūdinantys požymiai tiesiogiai neapibūdina funkcionavimo rezultato. Darniosios plètros šalininkų teiginiai, kad kompaktinis, intensyvaus užstatymo, viešojo transporto ir daugiafunkcès struktūros požymius turintis miestas yra tikrasis tikslas, negali būti absoliutinami ir nepriklausomi nuo ekonominès, socialinès, demografinès, planavimo, teisinès, gamtinès ir kitokios aplinkos. Tuo labiau kad nèra susitarimo, kaip suprasti 
ir apskaičiuoti daugiafunkciškumą tam, kad būtų patvirtintas vystymo darnumas (Becue, Teller 2008). Todèl pasitikèjimas minètais požymiais, kaip efektyvumo garantais, yra apriorinis.

Vilniaus struktūrinė analizè rodo, kad tarp urbanistinès struktūros požymių ir kiekybinių bei kokybinių funkcionavimo pasekmių gali egzistuoti statistinis ryšys. Būdingesni pavyzdžiai:

\begin{tabular}{llr}
\hline $\begin{array}{l}\text { Morfostruktūros } \\
\text { požymiai }\end{array}$ & Pasekmių požymiai & $\begin{array}{r}\text { Efektai (R): } \\
+-\end{array}$ \\
\hline $\begin{array}{l}\text { Funkcinės integraci- } \\
\text { jos laipsnis }\end{array}$ & VT naudojimo dažnis & $0,5-0,6$ \\
\cline { 2 - 3 } & LA naudojimo dažnis & $0,0-0,2$ \\
\cline { 2 - 3 } & susisiekimas pèsčiomis & $0,0-(-0,3)$ \\
\hline Gyventojų tankis & paslaugų prieinamumas & 0,7 \\
\cline { 2 - 3 } & narkomanija & 0,5 \\
\cline { 2 - 3 } & nesaugos jausmas & 0,6 \\
\hline Užstatymo tankis & triukšmas kieme & 0,6 \\
\cline { 2 - 3 } & finansinè grąža & $1^{*}$ \\
\cline { 2 - 3 } & gyventojų darbingumas & 0,5 \\
\hline
\end{tabular}

Pastabos: $R$ - koreliacijos koeficientas ir jo reikšmés; ${ }^{*}$ ekspertinis vertinimas; plačiau apie tai Juškevičiaus, Valeikos monografijoje (2007).

Šiuo atveju analizè atlikta naudojant prieinamą Vilniaus miesto 41 rajono (vidutiniai dydžiai: plotas apie 10 kv. km, gyventojų apie 13 tūkst.) informaciją. Jeigu būtų galimybè pasirinkti rajonų, kaip struktūrinių dalių, dydžius su atitinkama informacija, analizès rezultatai būtų kitokie. Tačiau ir turimi argumentai leidžia kelti hipotezę, kad miesto struktūros savybès su tam tikra tikimybe gali lemti miesto funkcionavimo pasekmių savybes. Tačiau jos su didele tikimybe bus prieštaringos naudingumo prasme. Todèl kiekvienos struktūros efektyvumas turi būti patikrintas konkrečiais skaičiavimais.

\section{Struktūra ir žemès naudojimas}

Grịžtant prie funkcinès integracijos principo žemės esamo ar planuojamo naudojimo turinys plačiaja prasme yra esminis struktūrinių dalių požymis. Makrostruktūriniam urbanistiniam planavimui tikslinga perimti kitų šalių, pavyzdžiui, Prancūzijos, patirtị (Le plan... 2008). Palyginamoji Europos (Cullingworth, Nadin 2001), Amerikos (Lubowski et al. 2002), Australijos planavimo (State Planning Policy 2006) sistemų analizė parodè, kad daugumos šalių (žemynų) planavimo sistema, o ypač žemės naudojimo klasifikavimas bendrojo planavimo lygmenyje skiriasi nuo taikomų Lietuvoje. Esminis skirtumas, kad nei vienoje iš toliau minimų planavimo sistemų nèra akcentuojama būtinybè avansu numatyti planuojamos žemès funkcinius požymius, svarbiausias reikalavimas, keliamas planuojamoms teritorijoms - laikytis nacionalinès (regioninès) politikos ir darniosios plètros, t. y. funkcinio integruotumo principų.

Pagal Prancūzijos planavimo sistemos analogiją standartizuoto klasifikavimo teritorijos būtų tokios:

$\mathrm{U}$ - u rb a n i z u o to s, nustatomos pagal pagal užstatymo glaudumo ir funkcinès veiklos integracijos kriterijus;

UA - u rb a nizu oj a mo s, identifikuojamos kaip suburbanizuotos, miesto ištisinio vystymo ir tolesnès ateities plètros rezervas, metropolio ekspansijos zona, žemės ūkio reliktai, miesto ūkis, rekreacijos ir kita. Iš esmès tai būtų problemiškiausia ir pagal dabartines tendencijas dinamiškiausia zona;

A - a g r a r i n è s (žemès ūkio), identifikuojamos kaip svarbiausias žemès ūkio gamybos potencialas, su jomis susiję gamybos ir aptarnavimo kompleksai, kaimai, kaimo turizmas;

$\mathrm{N}$ - n a t ū r a li o s (gamtinès): miškai, parkai, vandenys, naudingụjų iškasenų plotai, kariniai ir kitokie poligonai.

Kitų šalių planavimo sistemoje pagrindinių standartizuotų klasifikavimo teritorijų skaičius varijuoja tarp 2-6-ių pagrindinių žemės naudojimo paskirčių. Pvz., JAV 2005 m. Rokingemo planas - naudojami šeši tipai pagal esamas paskirtis (gyvenamosios, žemès ūkio, rekreacinès, komercinès, pramonès ir socialinès infrastruktūros paskirties teritorijos) ir šeši tipai planuojamoms teritorijoms apibūdinti (užstatytos, užstatytų teritorijų plètros arealai, ekonominès plètros, kaimiškųjų teritorijų plètros ir kaimiškosios agrarinès (neplanuojamos) teritorijos)). Didžiojoje Britanijoje teritorijos klasifikuojamos pagal šiuos esminius požymius: urbanizuotos teritorijos, ekonominès plètros ir gyvenamųjų teritorijų plètros, natūralios aplinkos bei kaimiškosios teritorijos. Kai kuriuose planuose kaip atskiras žemės naudojimo tipas išskiriamos inžinerinès infrastruktūros teritorijos. Tačiau Australijos planavimo sistemoje išskiriami tik du pagrindiniai žemès naudojimo tipai - rezervuotos teritorijos ir kitos zonos, kur prie rezervuotų ar rezervuojamų teritorijų priskiriamos rekreacinès, valstybinių miškų ir net inžinerinès infrastruktūros teritorijos, o kitos teritorijos yra skaidomos ị pramonines, kaimiškąsias, gyvenamąsias, ịvairiai naudojamas ir pan. (pvz., Two Rocks local ... 2005).

Tai būtų I-ojo lygmens vienintelis privalomas žemès naudojimo klasifikavimas. Bet kurio analizès ar planavi- 
mo objekto teritorijos tolesnis struktūrizavimas turi būti planuotojo kompetencija, nes tai priklauso nuo konkrečių planavimo tikslų, mastelio, objekto dydžio, jo sisteminio rango ir specifinių funkcinių bei kitų savybių.

Todèl kiekvienas standartizuotas žemès naudojimo tipas U, UA, A, N gali būti diferencijuotas ị $x, y, z$, q II-ojo lygmens žemès naudojimo tipus. Kiekvienas $\mathrm{Ux}, \ldots$ Nq tipas gali būti dar diferencijuotas ị III-ojo lygmens tipus. Užsienio šalių patirtis rodo, kad II-ojo ir III-ojo lygmens tipų yra labai daug, nes kiekvienas miestas, regionas ar kita planuojama teritorija turi originalią žemès naudojimo tipų kombinaciją (De Brest ... 2008; De St-Visent-de-Boisset 2008, Mairie de Quimper ... 2008). Pavyzdžiui, nagrinèjant pastaruoju metu parengtus planus (Canterbury ... 2006; Stirling ... 2006) Jungtinèje Karalystėje akivaizdu, kad nèra bendrai šalies mastu reglamentuojamų II-ojo, III-ojo lygmenų žemès naudojimo tipų. Bendros planavimo gairès ir procedūros pateiktos Planavimo akte, o visa kita yra nulemta planuotojo (organizatoriaus ir rengejjo) kompetencijos priklausomai nuo to, kokiu masteliu ir kokiam laikotarpiui yra rengiamas (ar atnaujinamas) planas.

Bet kurio lygmens žemės naudojimo tipas, žymimas $\mathrm{U}, \mathrm{Ux}, \mathrm{Ux} 1, \ldots$ ir t. t., yra tik simbolis, nurodantis esmini žemès naudojimo požymį, o už jo slypi funkciškai ir fiziškai mišrus žemès (galima sakyti ir erdvès) naudojimas.

Toks principas pirmiausia buvo panaudotas Vilniaus, vèliau Druskininkų, Šilutès, Šilalès miestų, Elektrènų, Širvintų, Ukmergès, Šilutès, Šilalès rajonų teritorijų bendruosiuose planuose (BP). Investiciju ir būsimo žemès naudojimo neapibrèžtumo sąlygomis pagrindiniai privalumai yra tokie: padidèjo BP sprendinių gyvybingumas erdvejje ir per tam tikrą laiką, nes leido bent iš dalies išvengti privalomųjųžemès naudojimo paskirčių, būdų ir pobūdžių, Prokrusto lovos bei išlaikyti planavimo logiką, padidinti informatyvumą.

Pirma, pastarųjų metų bendrojo planavimo patirtis parodè, kad struktūrų formavimas nepatenka ị didžiausio suinteresuotumo ratą, palyginti su tiesioginiu žemès savininkų suinteresuotumu padidinti žemès naudojimo ìvairovę ir hipotetinę vertę. Antra, įvertinant daugumos savivaldybių realų urbanistinio planavimo pajègumą ir gebejimus, galima teigti, kad standartinis BP yra neužbaigtas, nes tarp jo sprendinių ir sklypo detaliojo plano yra didelis atotrūkis (jis sumažètų, jeigu planavimo sistemoje atsirastų suplanavimo projektas). Trečia, sprendinių igyvendinimas nèra reglamentuotas, todèl didelè atsitiktinio ir chaotiško užstatymo tikimybė; nèra ir prievolès deklaruoti miesto urbanistinę politiką. Taigi galima daryti išvadą, kad kiekvieno struktūrinio vieneto žemès naudojimo tipui reikalingas reglamentas. Jo turinys:

a. reži mas (pavieniai režimai, galimos jų kombinacijos):

$S$ - saugojimas. Tai ne vien saugomų teritorijų nuostatos, bet ir apskritai saugojimo naudojant principai;

M- modernizavimas: revitalizavimo, regeneravimo, rekonstrukcijos, perplanavimo ir perstatymo bei kitokie elementai;

$\mathrm{K}$ - konversija;

SQ- nekeičiami nusistovèję vidiniai santykiai ir veikla;

NT - naujų teritorijų įsisavinimas, laisvų sklypų užstatytoje teritorijoje užstatymas;

$\mathrm{PD}$ - privalomas planavimo detalizavimas (prielaida suvaldyti užstatymo sklaidą);

SR - savivaldybès remiamos plètros teritorijos;

b. d r a u d i m a i (čia ir toliau pavyzdžiai): eksploatuoti iškasenas; naudoti teritoriją gyvenamiesiems automobiliams statyti; statyti sprogimo ir pan. riziką turinčias i̇mones; statyti hipercentrą miesto centre (mažų įmonių bankrotų prevencija);

c. sąlyg os statyti: galima statyti, jeigu iki nuotekų tinklų < $150 \mathrm{~m}$; jeigu statyba ar rekonstrukcija truks ne ilgiau kaip 1,5 metų; leidžiama statyti iki $30 \mathrm{kv}$. m priestatą nedidinant sklypo ploto; jeigu plètrai bus paimta ne daugiau kaip $10 \%$ naujai ịsisavinamų teritorijų;

d. g a t v è s: jungčių i viešą gatvę dažnis; minimalus važiuojamosios dalies plotis $5 \mathrm{~m}$; maksimalus akligatvių ilgis $250 \mathrm{~m}$;

e. in ž in e r i n i a i t i n k l a i: specifiniai techniniai, statybos, eksploatavimo reikalavimai, susiję su nuosavybès ir juridiniais reikalais;

f. a u to m obili ų statymas: jeigu aikštelès plotas $F>$ 1000 kv. m, jis turi būti apželdintas, įrengti takai; daugiabučiams namams nustatyta automobilių statymo norma 0,65 vietos butui plius 1 vieta $100 \mathrm{kv}$. $\mathrm{m}$ namo sklypo neužstatyto ploto;

g. la i s v o s e rdvè s: ne mažiau $10 \%$ gyvenamosios teritorijos ploto;

h. s t a t y b i n i a r reikalavimai: maksimalus pastatu aukštis; užstatymo intensyvumas; užstatomas plotas $\%$; tvorų aukštis; atstumai iki gatvès važiuojamosios dalies krašto.

Toks principinis žemės naudojimo tipų ir jų reglamentų reikalavimų variantiškumas yra prielaida $\mathfrak{i}$ bendraji planą integruoti specialiuosius planus, panaikinti išankstinių planavimo sąlygų reikmę, padidinti 
BP vertę, jo informatyvumą ir pragmatiškumą, gyvybingumą.

\section{Struktūrų reikšmès kaita}

Fizinès, funkcinès ir socialinès morfostruktūros yra inertiškos, tačiau kintančios. Vienas iš svarbiausių veiksnių - susisiekimo arba komunikavimo sistemų kaitos, vadinamos revoliucijomis, kurios iš esmès keite miestų sistemas. Yra 4 esminès revoliucijos nuo pèsčiųjų, viešojo ir lengvojo automobilio miesto bei tikètino informacinių technologijų miesto. Vilnius turi atitikmenis: iki maždaug $1960 \mathrm{~m}$. susiformavusị klasikini miestą su istoriškai susiklosčiusia daugiafunkce struktūra, kurią formavo ir dabar išliko svarbiausias susisiekimas pèsčiomis; vèlesnè beveik iki $1990 \mathrm{~m}$. plètra suformavo dezintegruotą struktūrą, tiesiogiai nulemtą viešojo transporto (VT) technologijų, jo paslaugu prieinamumo ir bet kurios veiklos priklausomybės nuo VT išsivystymo lygio, t. y. vadinamajji Atenų chartos miestą; šiandien dèl lengvuju automobilių visuotinio prieinamumo metropolizacijos banga formuoja išorinę struktūrą, kuri neturi tradicinių požymių - užstatymo principų, kompaktiškumo, funkcinès ir socialinès integracijos, viešųjų erdvių.

Šiandieninis etapas svarbus tuo, kad keičiasi urbanistinių struktūrų forma, vaidmuo ir reikšmè miesto funkcionavimui. Analizè rodo, kad automobilizacijos lygiui viršijus 400 aut. 1000 gyv., funkcinès integracijos ir fizinès struktūros požymiai, kaip veiksniai, neteko esminès įtakos gyventojų komunikaciniam ir lokalizaciniam mobilumui. Todèl urbanistinè struktūra taikoma dvejopai. Gyventojai, kurie susiję su VT, suinteresuoti tradiciniu struktūros efektyvumu, koreliuojančiu su daugumos gyvenimo būdo modeliu. Lengvụjų automobilių naudotojai suinteresuoti formuoti asmeninę struktūrą, kuri nèra pastovi nei laiko, nei erdvès požiūriu. Tokiu atveju svarbus tik gatvių tinklas ir galimybè surinkti kelionių grandinę, kuri asmeniškai yra efektyviausia (įvertinant ir gyvenamosios vietos lokalizaciją), nors kitais požymiais gali būti prieštaringa arba neapibrèžta.

Masiškas lengvụjų automobilių naudojimas mažina struktūrų formavimo aktualumą ir didina gyvenamosios funkcijos dispersiškumą, socialinių paslaugų, pramogų, kultūros funkcijų koncentraciją. Savotišku "stresu“ visai miesto sistemai galima vadinti hipercentrų ịsibrovimą ị susiklosčiusį užstatymą - išardomi susiklostę ryšiai, formuojasi nauji, keičiasi mobilumo pobūdis, gyvenimo būdas, gyvenamoji aplinka.
Dar tik pradedama stebèti ir nagrinèti informaciniu technologijų i̇taka miestų struktūrų pokyčiams ir sistemų funkcionavimui. Tačiau jau dabar galima įžvelgti kelias tendencijas:

televizijos (vidutiniškai apie 3,5 h gyv. per parą Lietuvoje), mobiliųjų telefonų (148 abonentai 100 gyv.), interneto (vidutiniškai apie $0,5 \mathrm{~h}$ gyv. per parą, $50 \%$ namų ūkių turi kompiuterius) galimybès gauti ir teikti informaciją, pramogas, paslaugas, bendrauti ir dirbti namuose visiškai nesusijusios su jokiomis urbanistinèmis struktūromis ir komunikaciniu mobilumu. Yra netiesioginis ryšys, nes kelionèms sutaupytas laikas skiriamas ne kam nors kitam, o vèl susisiekimui. Statistiškai tokį faktą patvirtina pastovi vidutinė 60 min gyventojų kelionių per parą trukmè. Tačiau mobilumo sklaida ir tikslai keičiasi. Viena iš hipotezių - sklaidos pobūdis labiau atsitiktinis; virtualaus mobilumo galimybè mažina komunikacinę atskirtị ir stiprina lokalizacinį pastovumą. Šiuo požiūriu virtualaus mobilumo augimo niša metropolio erdvės pjūvyje yra po susisiekimo pėsčiomis, viešuoju transportu, lengvuoju automobiliu zonų ir apima labiausiai nutolusias teritorijas;

gyventojų ir veiklos koncentracija garantuoja vadinamajjį aglomeracinį efektą, nes sumažina informacijos, žmonių, gèrybių apykaitos išlaidas. Tačiau didelis koncentracijos laipsnis gali pabloginti transportavimo, susisiekimo ir gyvenimo sąlygas bei išlaidas, žemès ir būsto, kitų pastatų, patalpų ịsigijimo, nuomos, eksploatavimo išlaidas. Visa tai yra dekoncentracijos veiksniai, kuriuos sustiprino lengvieji automobiliai. Informacinems technologijoms suteikiama dar svaresnè dekoncentracijos galia, kuri skatins urbanistinių struktūrų skeldèjimą ir nulems jų reikšmę.

\section{Struktūrų ịvertinimas}

Struktūrų ịvertinimas išlieka problema, nes teritorijų planavimo sistema numato vienintelę formą - politinị ịvertinimą. Tiesa, vertintojų institutui galima priskirti ịvairias visuomenès grupes, sektorines tarnybas, institucijas ir netgi de facto ị ši procesą ịsitraukiančias ministerijas. Tačiau tai nieko bendra neturi su sisteminiu ir su pagal iš anksto nustatytas taisykles vertinimu. Todèl profesionalus planuotojas privalo turèti visumą objektyvių argumentų, norèdamas diskutuoti su visuomenès grupèmis, politikais, sektorinèmis tarnybomis.

Kadangi urbanistinè struktūra suprantama kaip jos dalių tarpusavio išsidèstymas ir ryšiai, todèl ịvertinimas imanomas tik gretimybių principu: namo egzistavimas 
tarp kaimyninių namų, vieno rajono funkcionavimo tarp gretimų rajonų veiklos ir pan., remiantis gretimybių stiliaus, funkcinès, psichologinès darnos kriterijais, trečiųų asmenų interesais, servitutais ir t. t. Tai ribotos ar specifinès reikšmès būdas, nes juo negalima ịvertinti visos urbanistinès sistemos funkcionavimo kokybès.

Fizinè ir funkcinè, socialinè struktūra sudaro aplinką (neminint ekonominès, finansinès, gamtinès ir kt.), kurioje miestas funkcionuoja esant tam tikroms teigiamoms ir neigiamoms pasekmėms - išorès efektams, kurie ir gali būti sisteminiais kokybès indikatoriais:

M o b i l u m a s. Gyventojų kelionių dažnio, laiko ir piniginių išlaidų vidurkiai per dieną vienam gyventojui yra konstantos, nepriklausančios nuo struktūros ir miesto funkcionavimo. Mobilumo (km/gyv. per parą) dydis koreliuoja su miesto, šalies ekonominio išsivystymo lygiu. Mobilumo struktūra pagal kelionių tikslus ir susisiekimo būdus yra miesto veiklos išvestinè. Todèl struktūrų ịvertinimo požiūriu šiuolaikinè prioritetų eilute yra virtualus mobilumas, susisiekimas pèsčiomis, tramvajumi, troleibusu, autobusu, lengvuoju automobiliu. Faktinè eilutè yra atvirkščia. Tramvajaus įrengimas, pradètas prieš $30 \mathrm{~m}$., būtų veiksnys, galintis pradėti radikalius mobilumo ir Vilniaus urbanistinès struktūros pokyčius. Valstybè deklaruoja darniosios plètros principus, tačiau paradoksas - negalima išmatuoti, nes neveikia miestų raidos monitoringas. Taigi struktūrų ir sistemų ivvertinimas turètų prasidèti monitoringo sistemos veikla.

S r a u t a i (pèsčiųjų, automobilių ir kt.) yra mobilumo išvestinè. Apibendrintas dydis, pavyzdžiui, automobilių rida $\mathrm{R}$ aut. $\mathrm{km} /$ parą yra vienas iš planavimo kokybės rodiklių ir tikslas minimizuoti $\mathrm{R}$ dydị.

T a r ša. Kiekvienas R dydžio sumažèjimas reiškia energijos, kuro suvartojimo ir atitinkamai taršos bei triukšmo emisijos, eismo konfliktų ir socialinių laiko nuostolių sumažèjimą. Kitas žingsnis - taršos ir kitų išorès efektų sklaidos modeliavimas fizinèje struktūroje nustato tikètiną poveikị žmogui ir aplinkai.

Akivaizdu, kad išorès efektams nustatyti ir struktūroms ịvertinti reikalingi miesto e. modeliai. Sisteminiu principu veikiančiu modelių, išskyrus epizodinius atvejus Vilniuje, šalyje nèra. Todèl nesunku suprasti dabar galiojančiu reikalavimų, pageidavimų rengti SPAV ar monitoringo sistemas bendruosiuose planuose nepagrịstumą.

Urbanistinio planavimo reformos gairèse (Darnioji plètra... 2008) siūloma steigti teritorijų ir urbanistinio planavimo agentūrą, kurią sudarytų 5 regioniniai pa- daliniai. Viena iš daugelio veiklos sričių būtų planavimų ívertinimai ir monitoringo sistemos išlaikymas, nes maža tikimybè, kad tokius darbus pajègs atlikti visos savivaldybès, be to, tai apskritai būtų neracionalu. Tuo labiau kad palaipsniui teks pereiti prie išorès efektų monetarizavimo, nes ES tai jau užprogramuota. Be to, struktūrų îvertinimas nèra baigtinis dalykas. Jis bus periodinis arba priklausys nuo miesto plètros tempo. Todèl privalu grịžti prie tęstinio planavimo principų. Priešingu atveju neturi prasmès ir monitoringo sistema.

\section{Išvados}

Urbanistinių struktūrų formavimas ir sisteminis ịvertinimas išlieka kaip viena iš svarbiausių problemų, kurios egzistavimas mažina planavimo efektyvumą. Esminiai neigiami veiksniai slypi neišvystytoje ir nesistemiškoje planavimo sistemoje. Struktūrų formavimas nepatenka i didžiausio suinteresuotumo ratą, palyginti su žemès savininkų ir investuotojų suinteresuotumu padidinti žemès naudojimo ịvairovę ir vertę bei grąžą. Žemès naudojimo paskirtys, būdai ir pobūdžiai nekoreliuoja su urbanistinio planavimo tikslais, objektų fizine ir funkcine įvairove.

Svarbiausios prielaidos problemai spręsti:

- liberalizuoti ir perduoti planuotojo kompetencijai žemès naudojimo tipų ir formų bei reglamentų išsamaus turinio pagrindimą, koreliuojantị su konkretaus planavimo objekto savybėmis, problemomis ir vystymo tikslais;

- atsisakyti praktikos, kada verbalinis struktūrų apibūdinimas pripažįstamas a priori pakankama įvertinimo argumentacija, ir pereiti prie kokybiškai naujo sisteminio ịvertinimo, paremto miesto e. modeliais ir išorès efektų identifikavimu, jų monetarizavimu;

- pripažinti, kad planavimo sistemoje įteisinta vienintelè politinio įvertinimo forma negarantuoja objektyvumo, o dabartieje praktikoje sektorinių institucijų procedūrinis dalyvavimas ịgauna monopolinị ir nediskutuojamą pobūdį;

- įvertinti, kad keičiasi urbanistinių struktūrų forma, vaidmuo ir reikšmė miesto funkcionavimui. Esant aukštam, daugiau kaip 400 aut./1 000 gyv. automobilizacijos lygiui, funkcinès integracijos ir fizinès struktūros veiksniai netenka bendrinès reikšmès, nes vyrauja kintamų asmeninių erdvių paieška, taip pat ir išcentrinis lokalizacinis mobilumas - gyvenamosios erdvès paieška. Informacinès technologijos mažina gyventojų ir veiklos koncentracijos aglomeracini efektą, todèl prognozuojamos tolesnè urbanistinių 
struktūrų dekoncentracijos ir skeldejjimo tendencijos, tačiau su mažesniais neigiamais išorès efektais.

\section{Literatūra}

Becue, V.; Teller, J. 2008. Comment Concevoir un Quartier "Multifonction" Pour Promouvoir un Developpement Urbain Durable? Universite de Liege [interaktyvus], [žiūrèta 2008 10 21]. Prieiga per internetą: <www.unil.ch/webdav/site/ ouvdd/shared/Colloque\%202005/>.

Canterbury District Local Plan. 2006 [interaktyvus], [žiūrèta 200806 03]. Prieiga per internetą: <http://www.cartoplus. co.uk./canterbury/Canterbury.htm\#>.

Cullingworth, J. B.; Nadin, V. 2001. Town and Country Planning in the UK. London: Routledge. $481 \mathrm{p}$.

Darnioji plètra teritoriju planavime ir urbanistikoje. 2008. LNTPA. $110 \mathrm{p}$.

De Brest metropole oceane. Communaute urbaine. Plan local d'urbanisme [interaktyvus], [žiūrèta 200806 01]. Prieiga per internetą: <https://applications-internet.brest-metropole-oceane.fr./VIPDU72/plu/reglement/PLU-brest-metropole-oceane.pdf $>$.

De St-Vincent-de-Boisset. POS [interaktyvus], [žiūrèta 200806 01]. Prieiga per internetą: <www.saint-vincent-de-boisset. net/article>.

Goodal, B. 1987. Dictionary of human geografy. Penguin books. $509 \mathrm{p}$.

Juškevičius, P.; Valeika, V. 2007. Lietuvos miestu sistemu raida: monografija. Vilnius: Baltijos kopija. 240 p.

Le plan de zonage et sa signification [interaktyvus], [žiūrèta 200806 01]. Prieiga per internetą: <www.ceyzeriat.com/ urbanisme/plu/>.

Lubowski, R. N., et al. 2006. Major Uses of Land in the United States, 2002. Economic Information Bulletin No. (EIB-14), Economic Research Service/USDA. $54 \mathrm{p}$.

Mairie de Quimper. Plan d'occupation des sols [interaktyvus], [žiūrèta 200809 07]. Prieiga per internetą:<www.mairiequimper.fr/46655741/0/fiche-pagelibre/\&RH >.

Rockingham County Land Use Plan. [interaktyvus], [žiūrèta 200806 03]. Prieiga per internetą: <http://www.co.rockingham.nc.us/Planning/exsumfin.pdf $>$.

Stachowiak, K. 2004. System planowania przestrzennego Wielkiej Brytanii [interaktyvus], [žiūrèta 200810 06]. Prieiga per internetą: <www.zprie.amu.edu.pl/pliki/Wyklad-2druk.pdf >.

State Planning Policy 1. State Planning Framework Policy. Western Australia [interaktyvus], [žiūrèta 200810 20]. Prieiga per internetą: $<$ http://www.wapc.wa.gov.au/Publications/750.aspx $>$.

Stirling Local Plan. 2006 [interaktyvus], [žiūrèta 20080603 ]. Prieiga per internetą: <http://www.stirling.gov.uk/index/ services/planning/localplan/lp-1st-alteration/towns_and_ villages-3.htm >.

The Planning and Compulsory Purchase Act. 2004 [interaktyvus], [žiūrèta 20081021 ]. Prieiga per internetą: $<$ http://www.planningportal.gov.uk/england/professionals/ en/1085083698055.html>.
Two Rocks local planning scheme [interaktyvus], [žiūrèta 200810 26]. Prieiga per internetą: <http://www.wapc. wa.gov.au/Region+schemes/Metropolitan+Region+Scheme/25+000+Series/default.aspx $>$.

\section{PROBLEMS IN URBAN STRUCTURE FORMATION AND PRINCIPLES OF LAND USE CLASSIFICATION}

\section{P. Juškevičius, K. Jauneikaitė}

Abstract. Formation of urban structures and systematic evaluation remain one of the most important problems causing reduction of planning efficiency. The main negative factors result from undeveloped and nonsystematic planning system. Formation of structures doesn't gain access to the circle of the greatest interests, comparing with land owners' and developers' interests to increase the variety and value of land use. Procedural participation of sectorial institutions assumes monopolistic and nonnegotiable character in the present practice, and political judgement is the only evaluation form existing in planning system and it doesn't guarantee objectiveness. Land use purposes, types and subtypes don't correlate with urban planning objectives, physical and functional variety of objects. Links between formation of urban structures and principles of land use classification, informational welfare, structure evaluation principles, development intentions as well as correlation of their significance alternation with evolution of communication and informational technologies are analysed in this paper. Suggestions for solving problems in urban structure formation are set forward: to liberalize and transfer comprehensive reasoning of land use types, forms and regulation to the planner's competence, considering that the forms, role and significance of urban structures are changing, and proceed to a qualitatively new systematic evaluation, based on city e-models and identification and monetarization of external effects.

Keywords: planning system, structure, morphology, types of land use, criteria of systematic estimation, external effects.

\section{PRANCIŠKUS JUŠKEVIČIUS}

Dr Habil, Prof, Dept of Urban Design, Vilnius Gediminas Technical University (VGTU), Pylimo g. 26/Traku g. 1, LT-01132 Vilnius, Lithuania.E-mail: sj@amstudio.lt

Publications: author of over 70 research papers, 5 monographs. Projects: project leader of various land use (rural territories) plans, transport feasibility studies. Research interests: urbanism, land use planning for rural territories, planning public transport system.

\section{KRISTINA JAUNEIKAITE்}

Doctoral student, assistant, Dept of Urban Engineering, Vilnius Gediminas Technical University (VGTU), Sauletekio al. 11, LT-10223Vilnius, Lithuania.E-mail: kris@ap.vgtu.lt

Publications: author or co-author of 5 research papers. Projects: project leader or co-author of various land use planning projects. Research interests: mobility management, integration of mobility planning. 